\title{
A Study on Cone Factors for Northeastern Part of Shiwha Area I : Evaluation and Pore Pressure Parameter
}

\author{
Dae-Kyu Kim ${ }^{1 *}$ \\ ${ }^{1}$ Dept. of Civil Engineering, Sangmyung University \\ 시화지구 북동지역에서의 콘 계수 연구 I: \\ 값 결정 및 간극수압비 \\ 김대규 $^{1^{*}}$ \\ ${ }^{1}$ 상명대학교 건설시스템공학과
}

\begin{abstract}
The undrained strength of soils is open determined from the results of the piezocone penetration. The reliability of the value of the undrained strength lies on the cone factor value, whose evaluation needs a lot of experimental data and investigation for each site. In this study, the cone factors were evaluated for the northeastern part of Shiwha area in Gyunggi province using the experimental data of the field vane, unconfined compression, and UU triaxial compression tests. The values of the conventional cone factors $N_{k t}, N_{k e}, N_{\Delta u}$, and the new factor $N_{e}$ were determined to be 12, 11, 3, and 13, respectively. It was observed that there is a remarkable relationship between $N_{\Delta u}$ and the pore pressure ratio Bq.

요 약 지반의 비배수강도 값 결정을 위하여 최근 콘 관입시험 결과가 많이 활용되고 있다. 그러나 비배수강도 값 은 콘 계수 값에 절대적으로 의존하며, 해당 지역에 적합한 콘 계수 값의 결정을 위하여는 많은 시험결과의 축적 및 분석이 필요하다. 본 연구에서는 경기도 시화지구 북동지역 점성토 지반에 대하여 수행된 현장베인시험, 일축압축시 험 및 비압밀비배수 삼축압축시험 결과를 이용하여 각 시험결과별 콘 계수 값을 산정하였으며, 이를 비교 분석하였 다. 전통적 콘 계수 $N_{k t}, N_{k e}, N_{e}$ 및 새로운 콘 계수 $N_{e}$ 값들은 각각 $12,11,3,13$ 으로 산정되었으며, $N_{\Delta u}$ 와 간 극수압비 $\mathrm{Bq}$ 사이에 특정한 경향이 있음이 고찰되었다.
\end{abstract}

Key Words : Piezocone, Undrained strength, Cone Factor

\section{Introduction}

The undrained strength can be estimated from the empirical cone factor method using the cone penetration test. The method has been widely used since it is with relative ease(Lunne et al. 1997, Su et al. 2002, Kim 2009)[1,2,3].

There are generally three types of cone factors; $N_{k t}$ based on total cone resistance, $N_{k e}$ based on effective cone resistance, and $N_{\Delta u}$ based on excess pore water pressure. The three types of cone factors stated above result in the undrained strength through the Eqs. (1) (3), respectively(Lunne et al. 1985, Campanella et al. 1982, 1984) $\{4,5,6]$.

$$
\begin{aligned}
& s_{u}=\frac{\left(q_{t}-\sigma_{v o}\right)}{N_{k t}} \\
& s_{u}=\frac{\left(q_{t}-u_{2}\right)}{N_{k e}}
\end{aligned}
$$

This work was supported by Sangmyung University.

*Corresponding Author : Kim, Dae-Kyu(daekyu@smu.ac.kr)

Received November 21, 2011

Revised December 12, 2011

Accepted January 5, 2012 


$$
s_{u}=\frac{\left(u_{2}-u_{o}\right)}{N_{\Delta u}}
$$

where $s_{u}$ is the undrained strength, $q_{t}$ is the total cone resistance corrected for the pore pressure effect. $\sigma_{v o}$ is the in-situ total vertical stress. $u_{2}$ means the measured pore pressure immediately behind the cone tip. $u_{o}$ denotes the initial(static) pore water pressure. The results of various lab. and field testings determine the values of the cone factors $N_{k t}, N_{k e}, N_{\Delta u}$ at each site. Kim et al.(2008) proposed new correlation as Eq. (4) adopting the "effective cone factor" $N_{e}[7]$.

$$
s_{u}=\frac{\left(q_{t}-u_{o}\right)}{N_{e}}
$$

The value of $N_{e}$ could be evaluated 16.0 using the data of field vane testings and it was successfully applied for the soils in Songdo, Kwangyang, Pohang, Whajeon areas.

In this study, the cone factor values, for the soils in the northeastern part of Shiwha area in Gyunggi province, have been evaluated using the correlations as in $\mathrm{E} \mathrm{q} \mathrm{s}$. $(1 \sim 4)$ and the experimental results of field vane, unconfined compression, and UU triaxial compression testings. The determined values have been also investigated through the pore water pressure ratio $B_{q}$ in Eq. (5) which has been widely used for parametric study.

$$
B_{q}=\frac{u_{2}-u_{o}}{q_{t}-\sigma_{v o}}
$$

\section{Field Description}

The Shiwha area is western coast part of Gyunggi province and has been being developed since the sea wall was constructed. The overall area is so wide that the northeastern part of it is considered in this study.

The sub-soil consists of three layers. The upper layer is the soft sea sediment, which is mainly $\mathrm{CL}$ or, ML with $\mathrm{N}$ value of 1 to 6 in the depth of 6 to $16 \mathrm{~m}$ (unit weight $1.6 \sim 1.9 \mathrm{t} / \mathrm{m}^{3}$. water content $25 \sim 50 \%$, plastic index $8 \sim$ $50 \%$ ). The lower sedimentary layer is composed of silty sand and parts of stiff clay with $\mathrm{N}$ value over 6 in the depth of 15 to $25 \mathrm{~m}$ (unit weight $1.7 \sim 2.0 \mathrm{t} / \mathrm{m}^{3}$, water content $18 \sim 30 \%$, plastic index 5 20\%). The bed rock layer is heavily weathered and mainly constituted by silty sand(unit weight $2.1 \sim 2.3 \mathrm{t} / \mathrm{m}^{3}$, water content $7 \sim 25 \%$, plastic index $7 \sim 30 \%$ ). Fig. 1 shows the undrained shear strengths obtained from the unconfined compression test, the UU triaxial compression test, and the field vane test.

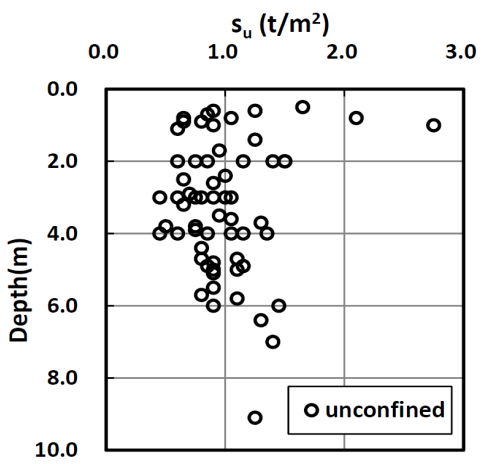

(a) Undrained strength(unconfined compression)

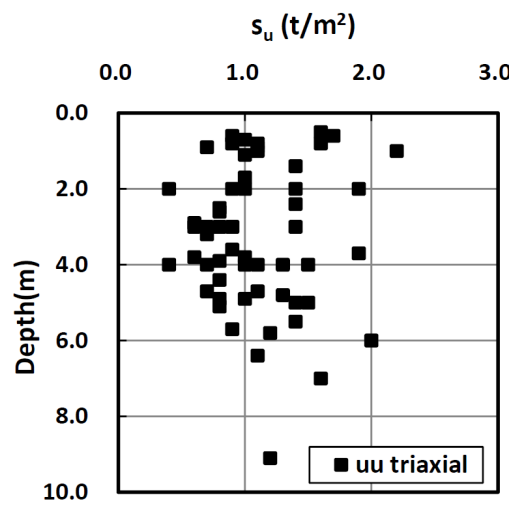

(b) Undrained strength(UU triaxial)

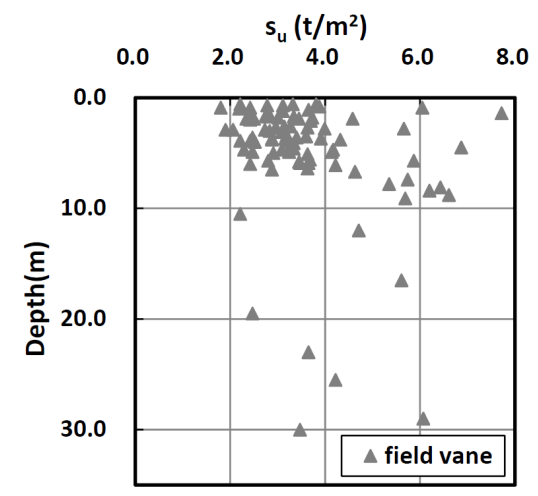

(c) Undrained strength(field vane)

[Fig. 1] Undrained Strength with Depth 


\section{Cone Factor Values}

The values of the cone factors $N_{k t}, N_{k e}, N_{\Delta u}, N_{e}$ were determined using Eqs. $(1 \sim 4)$ and the undrained strengths which were obtained from the three kinds of test results(Fig. 2).

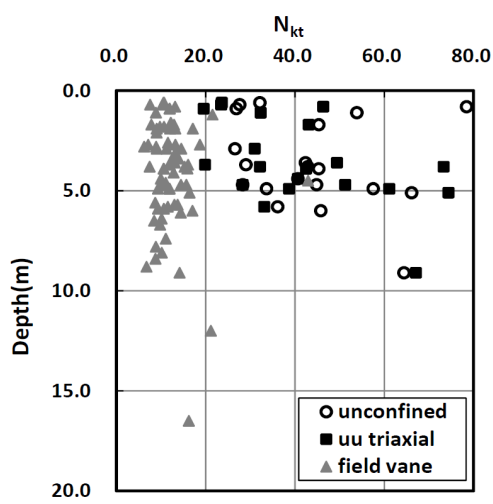

(a) $N_{k t}$ with depth

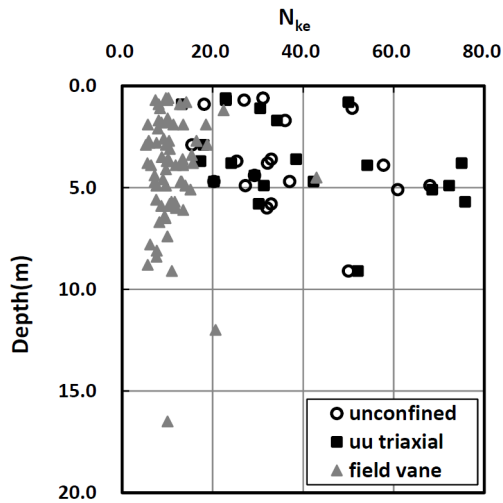

(b) $N_{k e}$ with depth

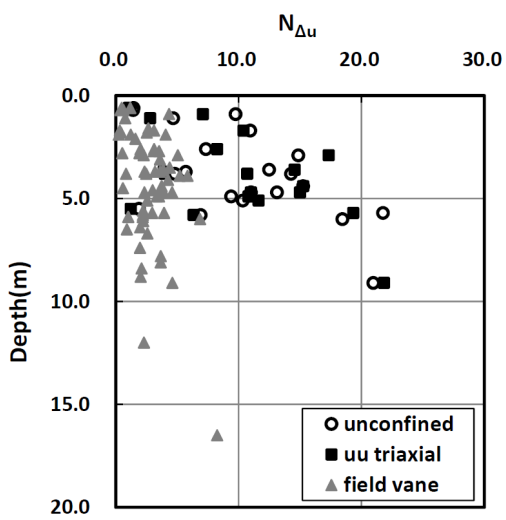

(c) $N_{\Delta u}$ with depth

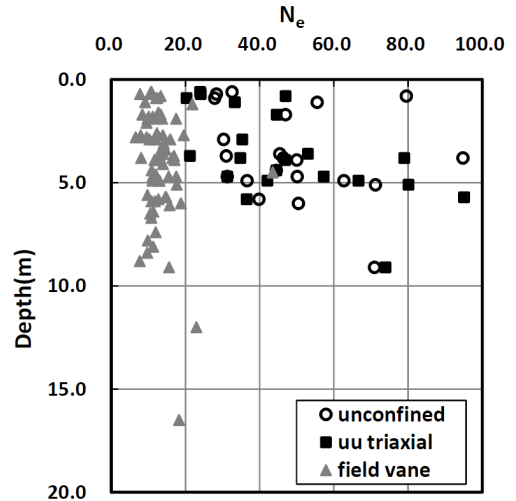

(d) $N_{e}$ with depth

[Fig. 2] Cone factor values with depth

The representative values of the cone factors are described in Table 1. The values from the field vane are smaller than the others because the undrained strength from the field vane are smaller. This is due to the sample disturbance for laboratory testings and the experimental error.

Tabel 1. Representative values

\begin{tabular}{|c|c|c|c|}
\hline $\begin{array}{c}\text { cone } \\
\text { factor }\end{array}$ & unconfined & UU triaxial & field vane \\
\hline$N_{k t}$ & 39 & 33 & 12 \\
\hline$N_{k e}$ & 33 & 28 & 11 \\
\hline$N_{\Delta u}$ & 8 & 7 & 3 \\
\hline$N_{e}$ & 42 & 36 & 13 \\
\hline
\end{tabular}

The undrained strength was calculated using the values from the field vane and compared with the measured values as in Fig. 3.

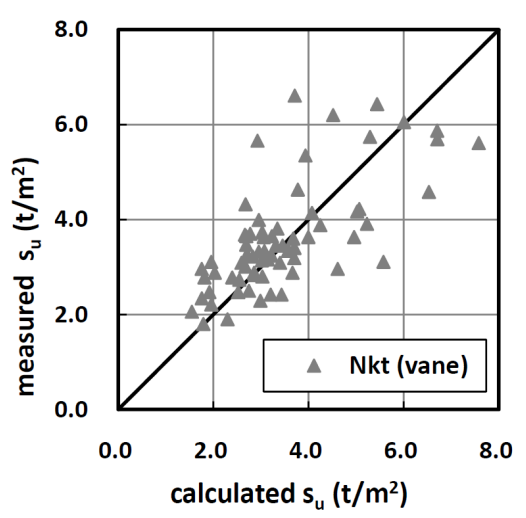

(a) using $N_{k t}$ (vane) 


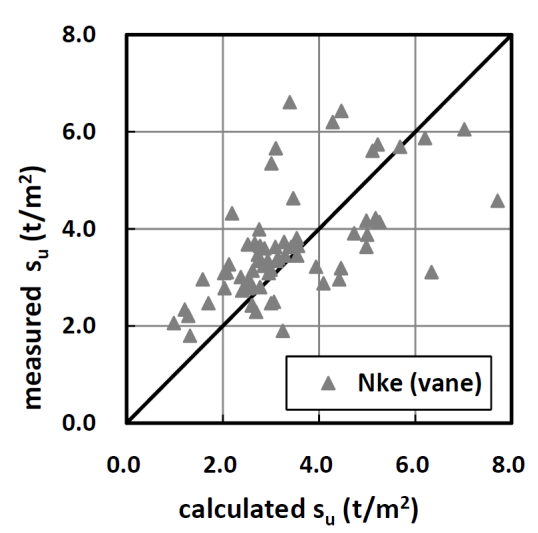

(b) using $N_{k e}$ (vane)

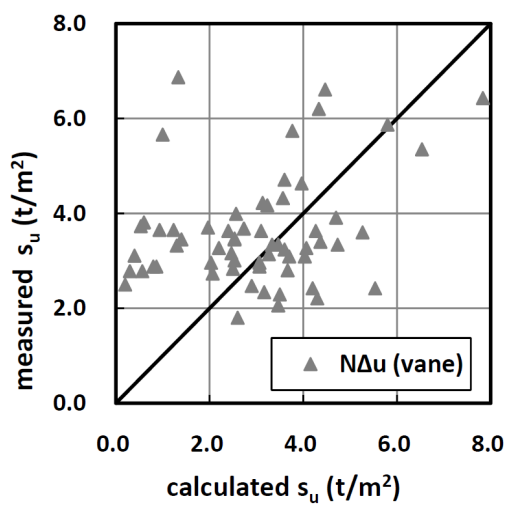

(c) using $N_{\Delta u}$ (vane)

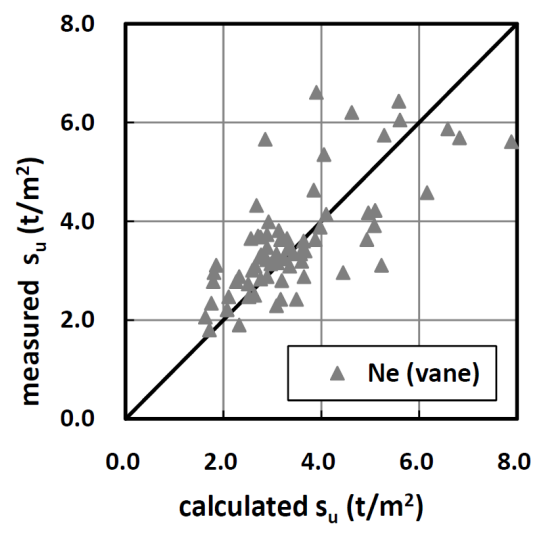

(d) using $N_{e}$ (vane)

[Fig. 3] Measured and calculated undrained strengths

It seems that $N_{\Delta u}$ does not show better result to consider the scattering of the data, on the contrary, the new factor $N_{e}$, which has the advantage that it does not take overburden pressure and excess pore water pressure during cone penetration into account, presents good result and implies the possibility of the use of a standard cone factor.

\section{Pore Water Pressure Ratios}

The pore pressure ratio $B_{q}$ is regarded as a reliable index as it involves such soil conditions as overburden stress, tip resistance, penetration pore pressure, and static pore pressure(Eq. 4). The relationship between $B_{q}$ and the cone factors are presented in Fig. 4.

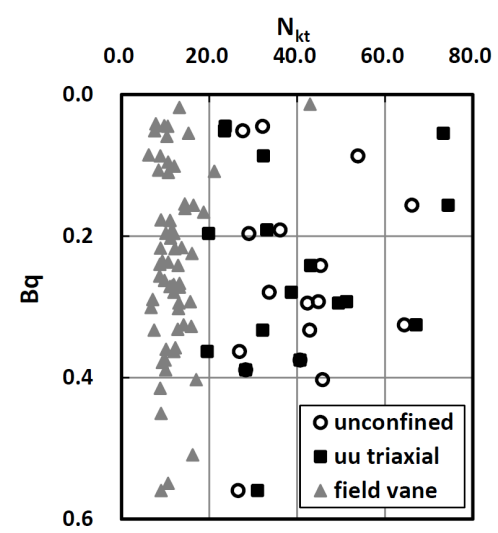

(a) $N_{k t}$ with $B_{q}$

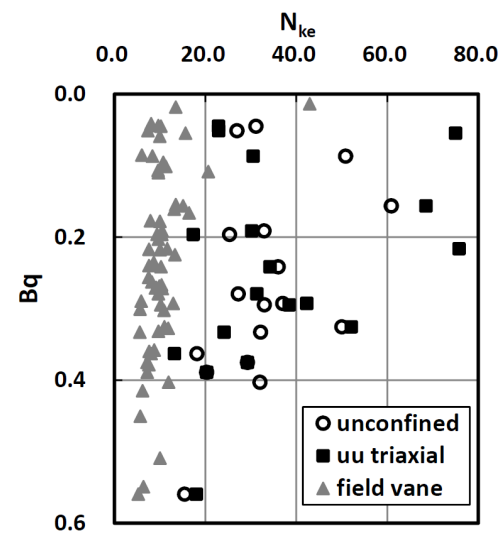

(b) $N_{k e}$ with $B_{q}$ 


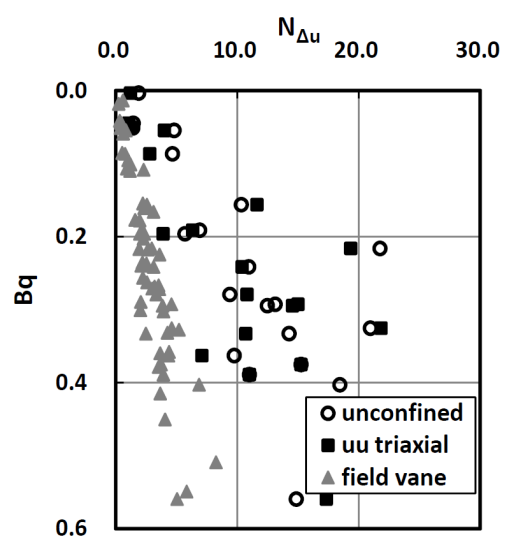

(c) $N_{\Delta u}$ with $B_{q}$

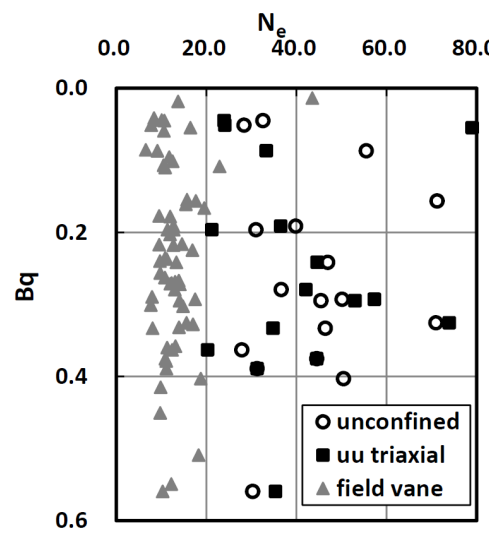

(d) $N_{e}$ with $B_{q}$

[Fig. 4] Cone factors with $B_{q}$

In Fig. 4, $B_{q}$ denotes the remarkable trend with $N_{\Delta u}$ from all three test results, despite the scattered results with no relevant relationships in Figs. 2 and 3, unlike the other cone factors. This is the same situation as in previous study(Kim 2009)[3]. The study on $B_{q}$ is further needed to figure out the correlations of undrained strength- $N_{\Delta u}-B_{q}$.

\section{Conclusions}

In this study, the four kinds of cone factors were evaluated using the experimental results of the unconfined compression test, UU triaxial test, and the field vane tes for the northeastern part of Shiwha area. The values and $B_{q}$ were investigated and the following conclusions could be formed.

- The values of $N_{k t}, N_{k e}, N_{\Delta u}$, and $N_{e}$ obtained from the field vane test are 12, 11, 3, and 13, respectively

- It might be possible that the new cone factor $N_{e}$ could be used as a standard cone factor.

- The pore pressure ratio $B_{q}$ presented the notable relationship with $N_{\Delta u}$ from all the three kinds of test results, The correlations of $N_{\Delta u}$ and $B$ could be a clue to get more reliable undrained strength.

\section{Acknowledgments}

Financial support for this research was provided through a grant "2010 Research fund of Engineering Research Institute" by Sangmyung University.

The author also acknowledges the Dodam Engineering for providing the valuable test data.

\section{References}

[1] T. Lunne, P. K. Robertson, J. J. M. Powell, Cone Penetration Testing, Blackie Academic and Professional, 1997.

[2] S. F. Su, H. J. Liao, "Influence of Strength Anisotropy on Piezocone Resistance in Clay," J. of Geotechnical and Geoenvironmental Engineering, pp. 166-173, Vol. 128, No. 2, Feb., 2002.

[3] D.K. Kim, "Interpretation of Empirical Cone Factors for Determining Undrained Strength," J. of Korea Academia-Industrial Cooperation Society, pp. 3296-3301, Vol. 10, No. 11, November, 2009.

[4] T. Lunne, H. P. Chrisoffersen, T. I. Tjelta, "Engineering Use of Piezocone Data in North Sea Clays," Pro. 11th Int. Conf. on Soil Mechanics and Foundation Engineering, Sanfrancisco, pp. 907-912, Vol. 2, 1985.

[5] R. G. Campanella, D. G. Gillespie, P. K. Robertson, "Pore Pressure during Cone Penetration Testing," Pro. 2nd European Syposium on Peneration Testing, Amsterdam, pp. 507-512, Vol. 2, 1982.

[6] R. G. Campanella, P. K. Robertson, D. G. Gillespie, J. Greig, "Recent Developements in insitu Testing of Soils," Pro. 11th Int. Conf. on Soil Mechanics and 
Foundation Engineering, Sanfrancisco, pp. 849-854, Vol.

2, 1985 .

[7] C..D. Kim, S.I. Kim, J.W. Lee,, "Estimation of Undrained Shear Strength for Clays using Effective Cone Factor," J. of Korean Society of Geotechnical Engineers, pp. 133-141, Vol. 24, No. 11, 2008.

\section{Dae-Kyu Kim}

[Regular member]

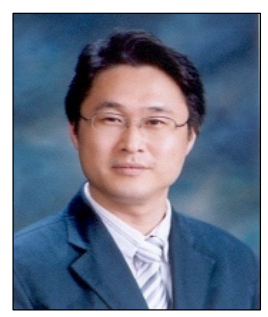

- Dec. 1999 : Louisiana State University, Ph.D.

- Mar. $2002 \sim$ current : Sangmyung University, Dept. of Civil Engineering, Associate Professor

$<$ Research Interests $>$

Geotechnical Engineering, Soils and Foundations, Ground Exploration and Testing, Constitutive Relations, Numerical Analysis, Underground 